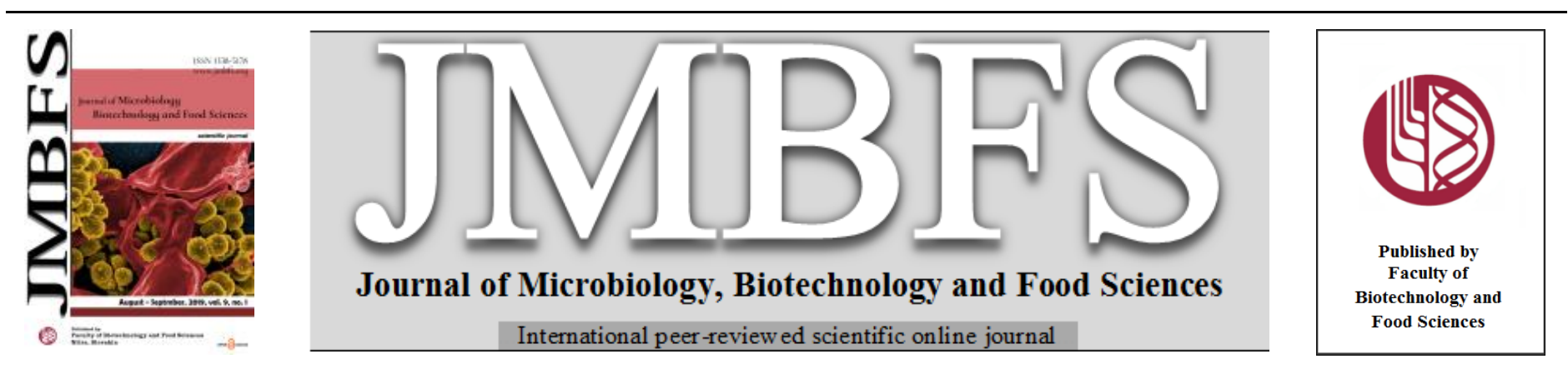

\title{
ASSESSMENT OF ANTIMICROBIAL POTENTIAL AND PHYTOCHEMICAL PROFILING OF ETHNOMEDICINAL PLANT BERGENIA CILIATA (HAW.) STERNB. IN WESTERN HIMALAYA
}

\author{
Rachna Verma* ${ }^{1}$, Ashwani Tapwal ${ }^{2}$,Dinesh Kumar ${ }^{3}$, Sunil Puri ${ }^{1}$
}

\begin{abstract}
Address(es):
${ }^{1}$ School of Biological and Environmental Sciences, Shoolini University of Biotechnology and Management Sciences, Bajhol, PO Sultanpur, Distt. Solan-173229 (HP), India.

${ }^{2}$ Himalayan Forest Research Institute, Shimla, H.P. India.

${ }^{3}$ School of Bioengineering and Food Technology, Shoolini University of Biotechnology and Management Sciences, Bajhol, PO Sultanpur, Distt. Solan-173229 (HP), India.

*Corresponding author: rachnac83@gmail.com

doi: 10.15414/jmbfs.2019.9.1.15-20

ARTICLE INFO

Received 24. 9. 2018

Revised 18. 2. 2019

Accepted 18. 2. 2019

Published 1. 8. 2019

Regular article

OPEN $\partial_{\text {ACCESS }}$

ABSTRACT

Western Himalaya is endowed with rich treasure of medicinal plant wealth. Bergenia ciliata is one of the important ethnomedicinal plants collected from Western Himalaya and used for dissolving kidney stones by the local inhabitants. In present work ethanolic rhizome extract of plant was evaluated for its medicinal potential by assessing its antimicrobial and phytochemical properties. In antimicrobial studies the ethanolic rhizome extract of the plant was used against standard and clinical isolates of selected pathogenic bacterial strains. Maximum inhibition zone $(12 \pm 1.0 \mathrm{~mm})$ was observed against clinical isolate of $S$. typhimurium followed by clinical isolate of $E$. coli with an inhibition zone of $11.33 \pm 0.57 \mathrm{~mm}$. The MIC of $B$. ciliata rhizome extract ranged from 100 to $200 \mu \mathrm{g} / 100 \mu \mathrm{l}$ against different pathogenic strains. The rhizome extract showed presence of reducing sugars, alkaloids, saponins, tannins, flavonoids and cardiac glycosides. Further, GC-MS analysis of rhizome extract confirmed the presence of phytochemicals viz., beta sitasterol, ethyl iso-allocholate, hexadecanoic acid, cetene, monolinolein TMS, berginin, gallic acid, linolool, $\beta$-caryophyllene, calcitriol, carotene, oleic acid and astaxanthin with significant ethnomedicinal importance.
\end{abstract}

Keywords: Ethnomedicinal plant, Western Himalaya, Antimicrobial potential, MIC, GC-MS analysis

\section{INTRODUCTION}

Medicinal and aromatic plants are predominantly present in the forest areas and a very few of these are also cultivated in agricultural fields. Some of these plants are used by the local people for their food, medicine and for other domestic purposes (Semwal et al., 2010). Ethnobotany has been variously defined and interpreted by different workers as this study follow methods based on knowledge and use of anthropological techniques (Rawat and Kharwal, 2013). Guleria and Vasishth (2009) documented the ethnobotanical use of plants by nomadic communities in Western Himalaya for varied medicinal purposes i.e. for curing stomach diseases, eye infection, fever, arthritis, blackening of hair, refreshing mind, loss of hairs, general weakness, loss of alertness, diabetes, loose motions and in impotency. Medicinal plants are used for preventive, promotive and curative purposes and serves as a main source of medicine in India (Sonowal and Barua, 2012). Herbal medicines have also been recognized by WHO (World Health Organization) as an important component for primary health care and about $11 \%$ of the 252 drugs are derived from plants sources (Shakya, 2016).

The Indian Himalayan Region (IHR) is a mega hotspot of biological diversity and comprises about $18 \%$ region of India with more than $2,800 \mathrm{~km}$ long and 220 to $300 \mathrm{~km}$ wide with altitudes ranging from 200-8000m (Myers et al., 2000; Chauhan et al., 2014). Shimla region in Himachal Pradesh, India lies between longitude 77.00" and 78.19" east and latitude 30.45" and 31.44" north and due to variable altitudinal and climatic conditions it is a vast repository of medicinal plants (Smith and Smith, 1899; Collet, 1902; Chauhan 1999; Verma et al., 2012; Singh and Thakur, 2014; Rana and Masoodi, 2014; Thakur, 2015; Chauhan et al., 2016; Verma et al., 2016). The western Himalayan region accounts for about $80 \%$ of herbal drugs in Ayurveda, $46 \%$ in Unani, and $33 \%$ of allopathic systems (Baragi et al., 2008). Since this region has diverse flora of medicinal plants, it has a great potential of raising the economy of its inhabitants (Sharma et al., 2014). Bergenia ciliata, an important plant of this region is used in the treatment of fever, diarrhoea and pulmonary infections (Farooquee $\boldsymbol{e t}$ al., 2004). It is used as an antipyretic, antidiabetic (alpha-glucosidase inhibitor) and antibacterial agent (Hsieh et $\boldsymbol{a l}$., 2001). A growing interest in existence of wild medicinal and aromatic plants in a locality and its role in improving the economy and welfare of the society has led to an increased research in this area. The present study attempts to postulate the medicinal importance of Bergenia ciliata collected from western Himalaya in terms of its antimicrobial and phytochemical potential.

\section{MATERIALS AND METHODS}

Plant collection

Bergenia ciliata (Haw.) Sternb. plant was collected from the Theog region (2500m amsl) of district Shimla, Himachal Pradesh, India, in western Himalaya. The plant was identified at Himalayan Forest Research Institute (HFRI), Shimla and the verified sample (voucher no: SUBMS/BOT/565) was submitted in Herbarium at the School of Biological and Environmental Sciences, Shoolini University, Solan, India. The collected rhizomes were washed with water to remove soil and dust particles and then dried thoroughly in shaded place. The dried rhizomes were grinded to fine powder and stored in an airtight container at room temperature and used to prepare the extract for further study.

\section{Preparation of bacterial strain}

Standard culture of five bacterial strains viz. Staphylococcus aureus (MTCC 737), Escherichia coli (MTCC 739), Klebsiella pneumoniae (MTCC 109), Salmonella typhimurium (MTCC 98) and Pseudomonas aeruginosa (MTCC 741) were procured from IMTECH Chandigarh, India. Clinical isolates of all these bacterial strains were obtained from PGIMER, Chandigarh and Indira Gandhi Medical College (IGMC), Shimla, India. All isolates were maintained by subculturing once in a month on nutrient agar and stored at $4{ }^{\circ} \mathrm{C}$. All standard and clinical isolates of the above bacterial strains were used for determining the antimicrobial property using ethanolic extract of B. ciliata. 


\section{Preparation of plant extract for antimicrobial activity}

The ethanolic rhizome extract of $B$. ciliata was prepared by using Selvamohan $\boldsymbol{e}$ al. (2012) method by dissolving $10 \mathrm{~g}$ fine powder of rhizome of this plants in $50 \mathrm{ml}$ of ethanol. The contents were kept in rotary orbital shaker for $48 \mathrm{~h}$ at $40^{\circ} \mathrm{C}$ Finally the extract was filtered through Whatman filter paper No. 1, dried at $40^{\circ} \mathrm{C}$ and stored at $4^{\circ} \mathrm{C}$ for further studies.

\section{Assay of antimicrobial activity using disc diffusion method}

The antimicrobial activity of the rhizome extract was determined by using Ahmady-Asbchin et al. (2013) and Tabaraki et al. (2013) method. For this $20 \mathrm{ml}$ of sterilized Muller Hinton Agar (MHA) was poured into sterile petriplate. The turbidity of inoculum was compared with 0.5 McFarland standards, containing $1-2 \times 10^{8} \mathrm{cfu} / \mathrm{ml}$. After solidification of MHA plates, $100 \mu \mathrm{l}$ of bacteria inoculums adjusted to an optical density (OD) of 0.8 were swabbed on the respective plates. Stock solution of plant extract $(20 \mathrm{mg} / \mathrm{ml})$ was prepared in ethanol and then different volumes of this extract i.e. $4 \mu 1,6 \mu 1,8 \mu 1$ and $10 \mu 1$ were transferred from stock on sterile Whatman No. 1 filter discs (at concentrations of $80 \mu \mathrm{g}, 120 \mu \mathrm{g}, 160 \mu \mathrm{g}$ and $200 \mu \mathrm{g} / \mathrm{disc})$. These discs were further placed on MHA plates and incubated for overnight at $37^{\circ} \mathrm{C}$. After incubation the diameter of inhibition zone formed around each discs was measured by using HiMedia inhibition zone scale. Ampicillin at a concentration of $10 \mu \mathrm{g} / \mathrm{disc}$ was used as a positive control and ethanol $(10 \mu 1 /$ disc $)$ was used as negative control.

\section{Minimum inhibitory concentration}

The modified method of Elshikh et al. (2016) was adopted for determination of minimum inhibitory concentration (MIC) in ethanolic rhizome extract of $B$ ciliata. Rhizome extract of plant were dissolved at twice the concentration in $100 \mu 1$ of Mueller Hinton broth (MHB) in each well of microtitre plate in column 1 , while columns 2-10 were dispensed with $50 \mu$ l of MHB broth only. Column 11 contained $100 \mu$ of diluted standard inoculum and column 12 contained $100 \mu$ of the MHB (as a control to monitor sterility). Further, 50 $\mu$ l of MHB from column 1 was transferred with micropipette from column 1 till column 10 , resulting in $50 \mu$ solution per well. A $50 \mu \mathrm{l}$ of bacterial suspension was then added to all the wells containing plant extract in MHB and also to the control wells. After incubation of microtitre plate for overnight at $37^{\circ} \mathrm{C}$, resazurin $(0.015 \%)$ dye was added to all the wells $(30 \mu \mathrm{l}$ per well), and incubated further for $2-4 \mathrm{~h}$ to observe the colour change. The microtiter well after which colour change was observed was scored as MIC of plant extract against respective culture under study.

\section{Phytochemical screening}

The phytochemical screening of ethanolic extract of $B$. ciliata rhizome was carried out to determine the presence of reducing sugars, alkaloids, saponins, tannins, flavonoids and cardiac glycosides as per the method given by Solomon et al. (2013).

\section{GC-MS analysis of the plant rhizome extract}

GC-MS analysis of the ethanolic rhizome extract of $B$. ciliata was performed using Thermo Scientific Triple Quadrupole GC-MS (Trace 1300 GC, Tsq 8000 triple quadrupole MS) equipped with TG $5 \mathrm{MS}(30 \mathrm{~m} \mathrm{X} 0.25 \mathrm{~mm}, 0.25 \mu \mathrm{m})$ column. Helium was used as the carrier gas at a flow rate of $1 \mathrm{ml} / \mathrm{min}$ using an injection volume of $1.0 \mu \mathrm{L}$. Injector temperature was kept at $250^{\circ} \mathrm{C}$ and ion source temperature was $230^{\circ} \mathrm{C}$. The oven temperature was maintained at $50^{\circ} \mathrm{C}$ isothermal at $280^{\circ} \mathrm{C}$. Mass spectra was taken at $70 \mathrm{eV}$ with scan interval of 0.5 seconds and fragments from 45 to $450 \mathrm{Da}$. Total GC running time used was 36 minutes. The phytochemicals of resolved components of test samples were identified by GC-MS NIST library to confirm the name, molecular weight and structure.

\section{Statistical analysis}

The values for each tests were calculated in triplicates as mean \pm standard deviation. Results were analyzed by one way ANOVA followed by Tukey's multiple comparison test $(\mathrm{P}<0.05)$ to find out the significant differences among the results. Graph Pad Prism software was applied for statistical analysis.

\section{RESULTS AND DISCUSSION}

B. ciliata an ethnomedicinal plant is used in the treatment of kidney stones by local people. The plant is found on the rocky surface or tree trunks at high altitude regions in Shimla district in western Himalaya. The scientific validation of medicinal potential of this plant was done by assessing its antimicrobial property and phytochemical analysis and the results of the study are discussed in following sections.

\section{Antimicrobial potential of $\boldsymbol{B}$. ciliata}

Antimicrobial activity of $B$. ciliata revealed that at maximum concentration of rhizome extract $(200 \mu \mathrm{g} /$ disc $)$ highest inhibition zone $(12 \pm 1.0 \mathrm{~mm})$ was observed against clinical isolate of $S$. typhimurium followed by $11.33 \pm 0.57 \mathrm{~mm}$ inhibition zone against clinical isolate of $E$ coli. No inhibition zone was observed in negative control. However, the inhibition zone in standard isolate of $K$. pneumoniae was $10.66 \pm 0.57 \mathrm{~mm}$, in standard isolate of $E$ coli this inhibition zone was $10.33 \pm 0.57 \mathrm{~mm}$ and in clinical isolate of $E$. coli it was $11.33 \pm 0.57 \mathrm{~mm}$. Results at all concentrations when compared with control were found significantly different while under different treatments $(120 \mu \mathrm{g} / \mathrm{disc}$ vs $160 \mu \mathrm{g} /$ disc, $120 \mu \mathrm{g} /$ disc vs $200 \mu \mathrm{g} / \mathrm{disc}$ ) these were found non-significant. The results of antimicrobial activity and MIC activity of rhizome extract of B. ciliata are shown in Table 1 and Table 2 respectively. The results showed that MIC was recorded $200 \mu \mathrm{g} / 100 \mu \mathrm{l}$ respectively against standard and clinical isolate of $P$. aeruginosa and $120 \mu \mathrm{g} / 100 \mu \mathrm{l}$ against clinical isolate of $S$. typhimurium. However, the MIC in rest of test microbes was found to be $100 \mu \mathrm{g} / 100 \mu \mathrm{l}$. Sinha et al. (2001) while working on antibacterial activity of $B$. ciliata reported that maximum zone of inhibition $(15 \mathrm{~mm})$ against $S$. aureus was observed by using concentration of $200 \mu \mathrm{g} / \mathrm{disc}$ and the minimum activity was observed against $P$. aeruginosa i.e. $3 \mathrm{~mm}$ with $200 \mu \mathrm{g} / \mathrm{disc}$. However, in present study an inhibition zone of $10 \mathrm{~mm}$ was observed with $B$. ciliata rhizome extract with concentration of $200 \mu \mathrm{g} / \mathrm{disc}$ which was also the MIC against same organism i.e. P. aeruginosa.

Table 1 Antimicrobial activity in rhizome extract of B. ciliata against different bacterial strains.

\begin{tabular}{|c|c|c|c|c|c|}
\hline \multirow{2}{*}{ Bacterial strains } & \multicolumn{5}{|c|}{ Antimicrobial inhibition zone (mm) } \\
\hline & Control & $80 \mu \mathrm{g} / \mathrm{disc}$ & $120 \mu \mathrm{g} / \mathrm{disc}$ & $160 \mu \mathrm{g} / \mathrm{disc}$ & $200 \mu \mathrm{g} / \mathrm{disc}$ \\
\hline $\operatorname{E.coli}(\mathbf{S})$ & $20.33 \pm 0.57^{\mathrm{a}}$ & ND & $10.00 \pm 0.00^{b}$ & $10.00 \pm 0.00^{b}$ & $10.33 \pm 0.57^{b}$ \\
\hline $\operatorname{E.coli}(\mathbf{C})$ & $21.00 \pm 0.00^{\mathrm{a}}$ & ND & $10.33 \pm 0.57^{b}$ & $10.50 \pm 0.50^{b}$ & $11.33 \pm 0.57^{b}$ \\
\hline K.pneumoniae (S) & $19.00 \pm 0.00^{\mathrm{a}}$ & ND & $10.00 \pm 0.00^{b}$ & $10.33 \pm 0.57^{b}$ & $10.66 \pm 0.57^{b}$ \\
\hline $\begin{array}{l}\text { K.pneumoniae } \\
\text { (C) }\end{array}$ & $19.33 \pm 0.57^{\mathrm{a}}$ & ND & $10.00 \pm 0.00^{b}$ & $10.16 \pm 0.28^{b}$ & $10.66 \pm 0.57^{\mathrm{b}}$ \\
\hline $\begin{array}{l}\text { S.typhimurium } \\
\text { (S) }\end{array}$ & $20.33 \pm 0.57^{\mathrm{a}}$ & ND & $10.00 \pm 0.00^{b}$ & $10.33 \pm 0.57^{b}$ & $11.00 \pm 1.00^{b}$ \\
\hline $\begin{array}{l}\text { S.typhimurium } \\
\text { (C) }\end{array}$ & $19.66 \pm 0.57^{\mathrm{a}}$ & ND & $10.00 \pm 0.00^{b}$ & $11.00 \pm 1.00^{b}$ & $12.00 \pm 1.00^{b}$ \\
\hline S.aureus (S) & $18.00 \pm 0.00^{\mathrm{a}}$ & ND & $10.66 \pm 0.57^{b}$ & $10.50 \pm 0.86^{b}$ & $11.00 \pm 1.00^{b}$ \\
\hline S.aureus $(\mathbf{C})$ & $18.33 \pm 0.57^{\mathrm{a}}$ & ND & $10.33 \pm 0.57^{b}$ & $10.33 \pm 0.57^{b}$ & $11.00 \pm 1.73^{b}$ \\
\hline P.aeruginosa (S) & $20.00 \pm 0.00^{\mathrm{a}}$ & ND & ND & ND & $10.00 \pm 0.00^{b}$ \\
\hline P.aeruginosa (C) & $19.33 \pm 0.57^{\mathrm{a}}$ & ND & ND & ND & $10.33 \pm 0.57^{b}$ \\
\hline
\end{tabular}

Where $\mathrm{S}=$ Standard strain, $\mathrm{C}=$ Clinical isolate, Control=Ampicillin. Values are calculated as mean \pm standard deviation $(\mathrm{n}=3)$
and significant results are represented by different letters in superscript. 
Table 2 MIC in ethanolic rhizome extract of B. ciliata against selected bacterial strains Bacterial strains

Concentrations of rhizome extract $(\mu \mathrm{g} / 100 \mu \mathrm{l})$

\begin{tabular}{|c|c|c|c|c|c|c|c|c|c|c|}
\hline & 200 & $\begin{array}{c}10 \\
0\end{array}$ & 50 & 25 & 12.5 & 6.25 & 3.12 & 1.56 & 0.78 & MIC \\
\hline $\operatorname{E.coli}(\mathrm{S})$ & - & - & + & + & + & + & + & + & + & 100 \\
\hline K.pneumoniae $(\mathrm{S})$ & - & - & + & + & + & + & + & + & + & 100 \\
\hline K.pneumoniae $(\mathrm{C})$ & - & - & + & + & + & + & + & + & + & 100 \\
\hline S typhimurium (C) & - & + & + & + & + & + & + & + & + & 200 \\
\hline S.aureus (S) & - & - & + & + & + & + & + & + & + & 100 \\
\hline S.aureus (C) & - & - & + & + & + & + & + & + & + & 100 \\
\hline P.aeruginosa $(\mathrm{S})$ & - & + & + & + & + & + & + & + & + & 200 \\
\hline
\end{tabular}

Where +indicates bacterial growth and - indicates no bacterial growth, $\mathrm{S}=\mathrm{Standard}$ strain, $\mathrm{C}=\mathrm{Clinical}$ isolate

Chauhan et al. (2012a) and Pokhrel et al. (2014) observed that the leaf extract of $B$. ciliata had much lower antibacterial activity than its rhizome extract owing to the presence of important phytocomponents in rhizome then in the leaves. This plant has also been assessed for its anti-cancerous (Pokhrel et al., 2014; Chauhan et al., 2012a), antiulcer, antitussive (Ruby et al., 2012; Pokhrel et al., 2014), antibacterial (Hsieh et al., 2001), antidiabetic (Chauhan et al., 2012b), antimalarial (Rajput and Mandal, 2012) and antiviral (Rajbhandari et al., 2003) property in different regions.

Table 3 Phytochemical study of selected ethnomedicinal plant collected from Shimla district in H.P., India

\begin{tabular}{cccccc}
\hline Saponins & Flavanoid & $\begin{array}{c}\text { Reducing } \\
\text { Sugars }\end{array}$ & Tannins & Alkaloids & $\begin{array}{c}\text { Cardiac } \\
\text { Glycosides }\end{array}$ \\
\hline+ & + & + & + & + & + \\
\hline Where + indicates presence & & & &
\end{tabular}

Ahmad et al. (2018) also reported presence of terpenoids, tannins, flavonoids, saponins, steroids, alkaloids, tannins, flavonoids, coumarins and glycosides in the rhizome extract of $B$. ciliata plant in different regions of the world.

\section{GC-MS analysis of $B$. ciliata}

In rhizome extract of $B$. ciliata after GC-MS analysis, 26 phytochemicals were identified and most dominant were seen at RT 29.82, 33.38 and 25.17 occupying $12.94 \%, 12.92 \%$ and $9.53 \%$ area respectively (Fig. 1).

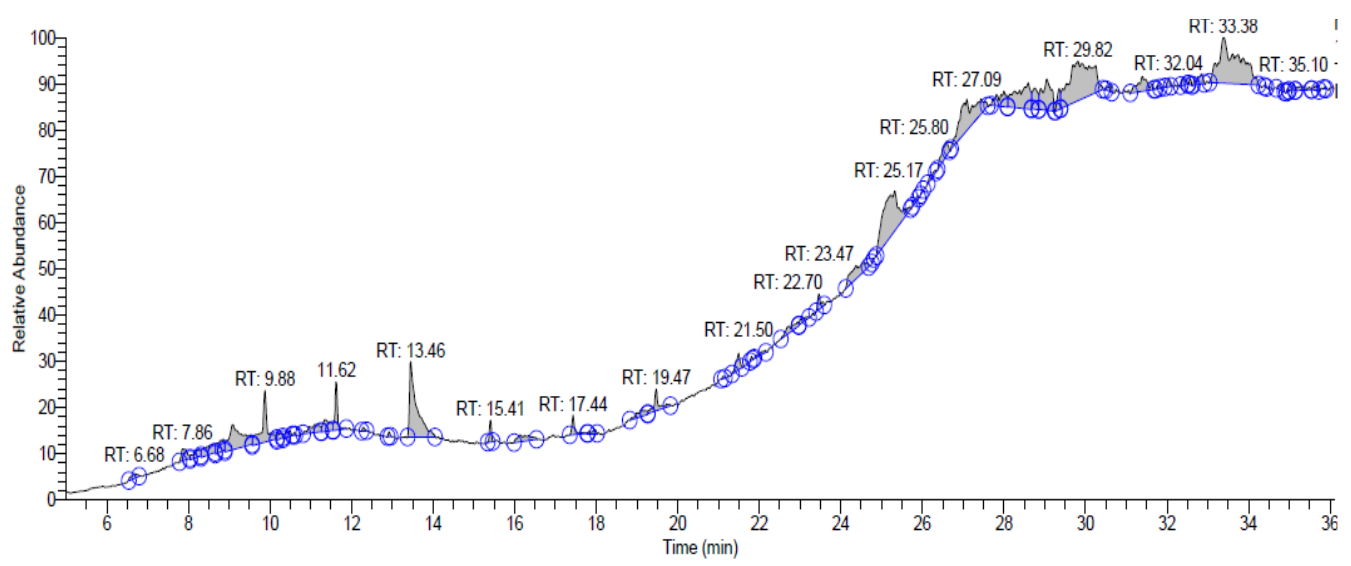

Figure 1 GC-MS analysis of rhizome extract of B. ciliata

The dominant phytochemicals includes 9,12,15 octadecatrienoic acid, 2,3bis[(trimethylsilyl) oxy]propyl ester, $(\mathrm{Z}, \mathrm{Z}, \mathrm{Z}) /$ 1-linolenoylglycerol at RT 29.82 followed by sitasterol at 33.38 RT. Sitasterol possess antioxidant, anthelmintic, anti-mutagenic, antidiabetic, hypocholesterolemic, antiinflammatory (Soodabeh et al., 2014) and cholestrol inhibition property (Ahmad et al., 2017) and 1-monolinoleoylglyceroltrimethylsilyl ether/ Monolinolein TMS (RT 25.17) possess antimicrobial, antioxidant, anti-inflammatory, anti-arthritic, anti-asthmatic and diuretic property (Hugar and Londonkar, 2017). All other identified phytochemicals in the rhizome extract are mentioned in Table 4 and the medicinally important phytochemicals are mentioned in Table 5. 
Table 4 Phytochemicals present in the rhizome extract of B. ciliata using GC-MS analysis.

\begin{tabular}{|c|c|c|c|c|c|}
\hline S. No. & Chemical & $\begin{array}{l}\text { Chemical } \\
\text { Formula }\end{array}$ & Mol wt & Area\% & $\begin{array}{l}\text { Retention } \\
\text { Time }\end{array}$ \\
\hline 1. & $\begin{array}{l}\text { 9,12,15 Octadecatrienoic acid, 2,3bis }[( \\
\text { trimethylsilyl)oxy]propyl } \quad \text { ester, } \quad(Z, Z, Z) / \\
\text { Linolenoylglycerol }\end{array}$ & $\mathrm{C}_{27} \mathrm{H}_{52} \mathrm{O}_{4} \mathrm{Si}_{2}$ & 496 & 12.94 & 29.82 \\
\hline 2. & Sitosterol & $\mathrm{C}_{29} \mathrm{H}_{50} \mathrm{O}$ & 414 & 12.92 & 33.38 \\
\hline 3. & $\begin{array}{l}\text { 1Monolinoleoylglyceroltrimethylsilyl } \\
\text { ether/Monolinolein TMS }\end{array}$ & $\mathrm{C}_{27} \mathrm{H}_{54} \mathrm{O}_{4} \mathrm{Si}_{2}$ & 498 & 9.53 & 25.17 \\
\hline 4. & Phthalic acid, butyl hex3ylester & $\mathrm{C}_{18} \mathrm{H}_{26} \mathrm{O}_{4}$ & 306 & 7.53 & 13.46 \\
\hline 5. & 2-Decenal & $\mathrm{C}_{10} \mathrm{H}_{18} \mathrm{O}$ & 154 & 7.08 & 27.09 \\
\hline 6. & Astaxanthin & $\mathrm{C}_{40} \mathrm{H}_{52} \mathrm{O}_{4}$ & 596 & 4.87 & 28.60 \\
\hline 7. & 4 Cetene/ 1-Hexadecene & $\mathrm{C}_{16} \mathrm{H}_{32}$ & 224 & 4.64 & 9.09 \\
\hline 8. & Tetradecamethyl hexasiloxane & $\mathrm{C}_{14} \mathrm{H}_{42} \mathrm{O}_{7} \mathrm{Si}_{7}$ & 593 & 3.83 & 9.88 \\
\hline 9. & Psi psi Carotene & $\mathrm{C}_{40} \mathrm{H}_{56}$ & 536 & 1.86 & 28.00 \\
\hline 10. & Octadecamethyl cyclononasiloxane & $\mathrm{C}_{18} \mathrm{H}_{54} \mathrm{O}_{9} \mathrm{Si}_{9}$ & 667 & 1.66 & 11.62 \\
\hline 11. & 9 Octadecenoic acid/oleic acid & $\mathrm{C}_{18} \mathrm{H}_{34} \mathrm{O}_{2}$ & 282 & 1.43 & 8.62 \\
\hline 12. & Linalool & $\mathrm{C}_{10} \mathrm{H}_{18} \mathrm{O}$ & 154 & 1.37 & 26.59 \\
\hline 13. & Beta-eudesmol & $\mathrm{C}_{15} \mathrm{H}_{26} \mathrm{O}$ & 222 & 1.33 & 19.47 \\
\hline 14. & Z10Tetradecen1ol acetate & $\mathrm{C}_{16} \mathrm{H}_{30} \mathrm{O}_{2}$ & 254 & 1.27 & 11.35 \\
\hline 15. & 4Octadecenal & $\mathrm{C}_{18} \mathrm{H}_{34} \mathrm{O}$ & 266 & 1.27 & 11.35 \\
\hline 16. & Ethyl iso-allocholate & $\mathrm{C}_{26} \mathrm{H}_{44} \mathrm{O}_{5}$ & 436 & 1.26 & $\mathbf{8 . 8 5}$ \\
\hline 17. & $\begin{array}{l}\text { 9Octadecenoicacid,(2phenyl1,3dioxolan4yl) methyl } \\
\text { ester, cis }\end{array}$ & $\mathrm{C}_{28} \mathrm{H}_{44} \mathrm{O}_{4}$ & 442 & 1.13 & 11.11 \\
\hline 18. & Hexanoic acid/Caproic acid & $\mathrm{C}_{6} \mathrm{H}_{12} \mathrm{O}_{2}$ & 116 & 1.07 & 16.14 \\
\hline 19. & Damascenone & $\mathrm{C}_{13} \mathrm{H}_{18} \mathrm{O}$ & 190 & 0.94 & 21.50 \\
\hline 20. & Hexadecanoic acid/Palmitic acid & $\mathrm{C}_{16} \mathrm{H}_{32} \mathrm{O}_{2}$ & 256 & 0.79 & 32.85 \\
\hline 21. & $n$-Pentacosane & $\mathrm{C}_{25} \mathrm{H}_{52}$ & 352 & 0.78 & 17.44 \\
\hline 22. & Berginin & $\mathrm{C}_{14} \mathrm{H}_{16} \mathrm{O}_{9}$ & 328 & 0.59 & 15.41 \\
\hline 23. & Azafrin & $\mathrm{C}_{27} \mathrm{H}_{38} \mathrm{O}_{4}$ & 426 & 0.41 & 34.79 \\
\hline 24. & Gallic acid & $\mathrm{C}_{7} \mathrm{H}_{6} \mathrm{O}_{5}$ & 170 & 0.34 & 10.25 \\
\hline 25. & Caryophyllene & $\mathrm{C}_{15} \mathrm{H}_{24}$ & 204 & 0.11 & 12.92 \\
\hline 26. & Calcitriol & $\mathrm{C}_{27} \mathrm{H}_{44} \mathrm{O}_{3}$ & 416 & 0.05 & 10.60 \\
\hline
\end{tabular}

Table 5 Medicinally important phytochemicals identified in the rhizome extract of $B$. ciliata
S.No. Chemical
Nature of chemical
compound
Reference

Antioxidant, anthelmintic and anti-mutagenic,

1. Beta sitasterol Sterol compound antidiabetic, hypocholesterolemic and anti-inflammatory

Cholestrol inhibition

Soodabeh et al., 2014

2. 1Monolinoleoylglyceroltrimethyls

$\begin{array}{ll}\text { 2. 1Monolinoleoylglyceroltrimethyls } & \text { Steroid }\end{array}$

Anti-microbial, anti-oxidant, anti-inflammatory, anti-

Ahmad et al., 2017

\begin{tabular}{ll} 
& ilylether/ Monolinolein TMS \\
\hline 3. Astaxanthin \\
\hline
\end{tabular}

\begin{tabular}{clc}
\hline 4. & Cetene & Aarotene \\
\hline 5. & Car \\
\hline
\end{tabular}

Tetraterpenoid A potential therapeutic agent in cardiovascular disease

Hugar and Londonkar, arthritic, anti-asthmatic, diuretic

2017

Alkene Antioxidant activity

\begin{tabular}{|c|c|c|c|c|}
\hline 5. & Carotene & hydrocarbon & cardiovascular diseases. & Bakiyalakshmi, 2016 \\
\hline 6. & Oleic acid & Fatty acid & $\begin{array}{c}\text { Cancer preventive, anemiagenic, insectifuge, } \\
\text { antiandrogenic, dermatitigenic. }\end{array}$ & $\begin{array}{l}\text { Vijisaral and Arumugam, } \\
2014\end{array}$ \\
\hline 7. & Linalool & Terpene alcohol & Food additives and shows bioactivity & Ahmad et al., 2018 \\
\hline 8. & Ethyl iso-allocholate & Steroid & $\begin{array}{c}\text { Anti-inflammatory, anticancer antimicrobial, } \\
\text { antiasthmatic, diuretic }\end{array}$ & Zekeya et al., 2014 \\
\hline
\end{tabular}

Antioxidant, pesticide, hypocholesterolemic, nematicide,

9. Hexadecanoic acid

Fatty acid

antiandrogenic, lubricant, flavor, hemolytic, 5-alpha

Shah et al., 2015 reductase inhibitor

\begin{tabular}{lllc}
\hline 10. & Berginin & Phenol & Antioxidant activity \\
\hline 11. & Gallic acid & Phenol & Antifungal, antiviral, cytotoxicity, antioxidant \\
\hline 12. & B-Caryophyllene & Sesquiterpene & Antimicrobial activity \\
\hline 13. & Calcitriol & Vitamin D3 & Ahmad et al., 2018 \\
\hline
\end{tabular}




\section{CONCLUSION}

B. ciliata plant generally found at high altitudes in the western Himalaya is well known for its medicinal potential in dissolving kidney stones. The medicinal property of pant is supported scientifically with antimicrobial potential reported in the present study. The dominant phytochemicals in the rhizome extract as observed by GC-MS analysis includes 9,12,15 octadecatrienoic acid, 2,3bis[(trimethylsilyl)oxy]propylester,(Z,Z,Z)/1-linolenoylglycerol, sitasterol and Monolinolein TMS which further scientifically supports the medicinal use of this important plant of western Himalaya.

Acknowledgement: The authors are thankful to Himalayan Forest Research Institute (HFRI), Shimla, Himachal Pradesh, India for identification of collected plant; Sophisticated Analytical Instrumentation Facility (SAIF), Panjab University, Chandigarh for GC-MS analysis of this ethnomedicinal plant and Shoolini University, Solan, India for providing all necessary facilities in the laboratory.

\section{REFERENCES}

ABDEL-WAHAB, M.A., BAHKALI, A.H.A., EL-GORBAN, A.M., HODHOD, M.S. 2017. Natural products of Nothophoma multilocularis sp. nov. an endophyte of the medicinal plant Rhazya stricta. Mycosphere, 8(8), 1185-1200. http://dx.doi.org/10.5943/mycosphere/8/8/15

AHMAD, I., KHAN, H., GILANI, A.U., KAMAL, M.A. 2017. Potential of plant alkaloids as antipyretic drugs of future. Current Drug Metabolism, 18(2), 138 144. https://dx.doi.org/10.2174/1389200218666170116102625

AHMAD, M., BUTT, M.A., ZHANG, G., SULTANA, S., TARIQ, A., ZAFAR, M. 2018. Bergenia ciliata: A comprehensive review of its traditional uses, phytochemistry, pharmacology and safety. Biomedicine and Pharmacotherapy, 97, 708-721. https://dx.doi.org/10.1016/j.biopha.2017.10.141

AHMADY-ASBCHIN, S., SAFARI, M., MORADI, H., SAYADI, V. 2013. Antibacterial effects of methanolic and ethanolic leaf extract of Medlar (Mespilus germanica) against bacteria isolated from hospital environment. Arak Medical University Journal, 16(75), 1-13.

BARAGI, P.C., PATGIRI, B.J., PRAJAPATI, P.K. 2008. Neutraceuticals in ayurveda with special reference to avaleha kalpana. Ancient Science of Life, 28(2), 29-32.

BOOMINATHAN, M., BAKIYALAKSHMI, S.V. 2016. Analysis of bioactive compounds in Navara (Njavara) rice by GCMS. International Journal of Recent Scientific Research, 7(11), 14307-14311.

CHAUHAN, N.S. 1999. Medicinal and Aromatic Plants of Himachal Pradesh. Indus Publishing Company, New Delhi. 632p. ISBN 8173870985.

CHAUHAN, P.K., SINGH, S., KOUR, J., SINGH, M. 2014. Need of conservation and management of endangered plant species of north western Himalayas- a review. World Journal of Pharmaceutical Research, 3(9), 222-226. CHAUHAN, P.P., NIGAM, A., SANTVAN, V.K. 2016. Ethnobotanical study of wild fruits in Pabbar valley, district Shimla, Himachal Pradesh. Journal of Medicinal Plants Studies, 4(2), 216-220.

CHAUHAN, R., KUMARI, R., DWIVEDI, J. 2012a. Bergenia ciliata mine of medicinal properties: a review. International Journal of Pharmaceutical Sciences Review and Research, 15(2), 20-23.

CHAUHAN, R., KUMARI, R., DWIVEDI, J. 2012b. Pashanbheda a golden herb of Himalaya: a review. International Journal of Pharmaceutical Sciences Review and Research, 15(2), 24-30.

COLLETT, H. 1902. FLORA SIMLENSIS. Thacker Spink and Co. Calcutta and Shimla, Reprint (1971). Bishan Singh. Mahendra Pal Singh Cannaught Place Dehra Dun, India 652p.

ELSHIKH, M., AHMED, S., FUNSTON, S., DUNLOP, P., MCGAW, M., MARCHANT, R., BANAT, I.M. 2016. Resazurin based 96-well plate microdilution method for the determination of minimum inhibitory concentration $\begin{array}{llll}\text { of biosurfactants. Biotechnology Letters, 38, } 1015 & \end{array}$ 1019. http://dx.doi.org/10.1007/s10529-016-2079-2

FAROOQUEE NA, MAJILA BS, KALA CP. 2004. Indigenous knowledge systems and sustainable management of natural resources in a high altitude society in Kumaun Himalaya, India. Journal of Human Ecology, 16, 33-42. https://dx.doi.org/10.1080/09709274.2004.11905713

FASSETT, R.G., COOMBES, J.S. 2011. Astaxanthin: a potential therapeutic agent in cardiovascular disease. Marine Drugs, 9(3), 447-465. https://dx.doi.org/10.3390\%2Fmd9030447

GULERIA, V., VASISHTH, A. 2009. Ethnobotanical uses of wild medicinal plants by Gaddi and Gujjar tribes of Himachal Pradesh. Ethnobotanical Leaflets, 13, 1158-1167.

GYAWALI, R., KIM, K.S. 2012. Bioactive volatile compounds of three medicinal plants from Nepal, Kathmandu University. Journal of Science Engineering and Technology, 8(1), 51-62. http://dx.doi.org/10.3126/kuset.v8i1.6043
HSIEH, P.C., MAU, J.L., HUANG, S.H. 2001. Antimicrobial effect of various combinations of plant extracts. Food Microbiology, 18(1), 35-43. https://dx.doi.org/10.1006/fmic.2000.0376

HUGAR, A.L., LONDONKAR, R.L. 2017. GC-MS profiling of bioactive components from aqueous extract of Pterocarpus marsupium. International Journal of Chem Tech Research, 10(90), 557-564.

MYERS, N., MUTTERMEIER, R.A., MUTTERMEIER, C.A., FONSECA, A.B.G., KENT, J. 2000. Biodiversity hotspots for conservation priorities. Nature 403, 853-858. https://dx.doi.org/10.1038/35002501

POKHREL, P., PARAJULI, R.R., TIWARI, A.K., BANERJEE, J. 2014. A short glimpse on promising pharmacological effects of Bergenia ciliata. Journal of Applied Pharmaceutical Research, 2(1), 1-6.

RAJBHANDARI, M., WEGNER, U., SCHOEPKE, T., LINDEQUIST, U., MENTEL, R. 2003. Inhibitory effect of Bergenia ligulata on influenza virus A. Pharmazie, 58(4), 268-271.

RAJPUT, S., MANDAL, M. 2012. Antitumor promoting potential of selected phytochemicals derived from spices: a review. European Journal of Cancer Prevention, 21(2), 205-215. http://dx.doi.org/10.1097/CEJ.0b013e32834a7f0c

RANA, D., MASOODI, H.U.R. 2014. Ethno-botanical survey for wild plants in fringe villages around Shimla. Journal of Applied and Natural Science, 6(2), 720724. https://dx.doi.org/10.31018/jans.v6i2.525

RAWAT, D., KHARWAL, A. 2013. Studies on traditional herbal pediatrics practices in Jaisinghpur, district Kangra (Himachal Pradesh, India). Global Journal of Research in Medicinal Plants and Indigenous Medicines, 2013, 2(4), 219-230.

RUBY, K., CHAUHAN, R., SHARMA, S., DWIVEDI, J. 2012. Polypharmacological activities of Bergenia species. International Journal of Pharmaceutical Sciences Review and Research, 13(1), 100-110.

SELVAMOHAN, T., RAMADAS, V., KISHORE, S.S.S. 2012. Antimicrobial activity of selected medicinal plants against some selected human pathogenic bacteria. Advances in Applied Science Research, 3(5), 3374-3381.

SEMWAL, D.P., SARADHI, P.P., KALA, C.P., SAJWAN, B.S. 2010. Medicinal plants used by local Vaidyas in Ukhimath block, Uttarakhand. Indian Journal of Traditional Knowledge, 9(3), 480-485

SHAH, A., SINGH, T., VIJAYVERGIA, R. 2015. GC-MS analysis of bioactive phytoconstituents from Rumex vesicarius L. International Research Journal of Pharmacy, 6(4), 269-272. http://dx.doi.org/10.7897/2230-8407.06459

SHAKYA, A.K. 2016. Medicinal plants: future source of new drugs. International Journal of Herbal Medicine, 4(4), 59-64.

SHARMA, A., SANTVAN, V.K., SHARMA, P., CHANDEL, S. 2014. Studies on traditional knowledge of ethnomedicinal plants in Jawalamukhi, Himachal Pradesh, India. International Research Journal of Biological Sciences, 3(10), 612.

SINGH, K.J., THAKUR, A.K. 2014. Medicinal plants of the Shimla hills, Himachal Pradesh: a survey. International Journal of Herbal Medicine, 2(2), 118-127.

SINHA, S., MURUGESAN, T., KUNTAL, M., GAYEN, J.R., PAL, B., PAL, M., SAHA, B.P. 2001. Antibacterial activity of Bergenia ciliata rhizome. Fitoterapia, 72, 550-552. https://dx.doi.org/10.1016/S0367-326X(00)00322-1

SMITH, E., SMITH, H.B. 1899. Shimla Flowers: An Annotated List of Flowers Collected in the Neighbourhood of Simla and Mashobra. Privately Printed, Simla and Calcutta. Common Medicinal Herbs of Shimla City, Himachal Pradesh, India. In Medicinal Plants: Distribution, Utilization and Significance Discovery Publishing House Pvt. Ltd., New Delhi.113-125.

SMITH, E.L., PINCUS, S.H., DONOVAN, L., HOLICK, M.F. 1988. A novel approach for the evaluation and treatment of psoriasis. Journal of the American Academy of Dermatology, 19(3), 516-528. https://dx.doi.org/10.1016/S01909622(88)70207-8

SOLOMON, C.U., ARUKWE, U., ONUOHA, I. 2013. Preliminary phytochemical screening of different solvent extracts of stem bark and roots of Dennetia tripetala G. Baker. Asian Journal of Plant Science and Research, 3, 1013.

SONOWAL, R., BARUA, I. 2012. Indigenous knowledge and bioresource utilization among the Tai-Khamyangs of Assam, North East India. International Research Journal of Biological Sciences, 1(7), 38-43.

SOODABEH, S., AZADEH, M., AHMAD, R.G., MOHAMMAD, A. 2014. The story of beta-sitosterol- a review. European Journal of Medicinal Plants, 4, 590 609. https://dx.doi.org/10.9734/EJMP/2014/7764

TABARAKI, R., NATEGHI, A., AHMADY-ASBCHIN， S. 2013. In vitro assessment of antioxidant and antibacterial activities of six edible plants from Iran. Journal of Acupuncture and Meridian Studies, 6(3), 159-162. http://dx.doi.org/10.1016/j.jams.2013.01.016

THAKUR, A.K. 2015. Common Medicinal Herbs of Shimla City, Himachal Pradesh, India. In Medicinal Plants: Distribution, Utilization and Significance. Discovery Publishing House Pvt. Ltd., New Delhi, 113-125.

VERMA, R., PARKASH, V., KUMAR, D. 2012. Ethnomedicinal uses of some plants of Kanag Hill in Shimla, Himachal Pradesh, India. International Journal of Research in Ayurveda and Pharmacy, 3(2), 319-322. 
VERMA, R., PURI, S. 2016. Antimicrobial, antioxidant and GC-MS profiling of Rumex obtusifolius L. an important ethnomedicinal plant of Himachal Pradesh

in North Western Himalaya. Medicinal Plants - International Journal of Phytomedicines and Related Industries, 8(3), 249- 254. http://dx.doi.org/10.5958/0975-6892.2016.00030.7

VIJISARAL, E.D., ARUMUGAM, S. 2014. GC-MS analysis of bioactive constituents of Indigofera suffruticosa leaves. Journal of Chemical and Pharmaceutical Research, 6(8), 294-300.

ZEKEYA, N., CHACHA, M., SHAHADA, F., KIDUKULI, A. 2014. Analysis of phytochemical composition of Bersama abyssinica by gas chromatography mass spectrometry. Journal of Pharmacognosy and Phytochemistry, 3(4), 246-252. 